\title{
Neo-Liberal Gelişme Anlayışı ve Kadın: Mikro Finans Uygulamaları Kadınları Güçlendiriyor mu?
}

\author{
The Neo-Liberal Development Paradigm and Woman: Do Micro-finance \\ Practices Empower Women?
}

\section{Özlem Irmak BALKIZ* Esra ÖZTÜRK ${ }^{* *}$}

Özet: Dünya çapında mikro kredi kullandıran organizasyonların amaçlarına bakıldığında "kadınları güçlendirme" söylemi dikkat çekmektedir. Ekonomik kontrolü kadınlara vererek aile içinde ve toplumda kadınların statüsünü yükseltmek, onları gelir sahibi yaparak bağımlılıktan kurtarmak gibi amaçlar taşıyan bu sistemin ataerkil düşünce yapısına alternatif bir mantık geliştirebilme potansiyeline sahip olup olmadığı araştırılması gereken bir husustur. Bu makalede mikro kredi uygulamasının kadınların ekonomik ve sosyal açıdan güçlendirilmelerinde etkin bir proje olup olmadığı, Diyarbakır'da mikro krediden faydalanan toplam 100 kadınla yapılmış görüşmelerle desteklenerek sorgulanmıştır. Araştırmanın sonuçlarına göre, alınan krediler yeni bir iş kurmaktan daha ziyade varolan bir işi devam ettirmek, borçların ödenmesi ya da acil ihtiyaçların karşılanması için kullanılmaktadır. Kadınların krediyle yaptıkları işler, geleneksel ev üretimi niteliğinde işler olup, ev dışında güvenceli, düzenli gelir getiren ve onları kamusal hayata sokan işler değildir. Bu işlerden elde edilen gelir düzeyi bir hayli düşük olup, aile açısından ek gelir olma statüsünden kurtulamamaktadır. Kadınların krediye erişimlerinin sağlanması ve hane gelirinin kısmen de olsa arttırılabilmesi, tek başına kadınların sosyal konumunda önemli bir değişim yaratmamaktadır.

Anahtar sözcükler: Mikro Kredi, Neo-Liberal Gelişme Anlayışı, Kadınların Güçlendirilmesi

Abstract: When the objectives of organizations around the globe providing microfinance are inquired into the expression "women's empowerment" becomes apparent. It should be investigated whether this system, which has such objectives as improving women's status within the family and society by leaving economic control to them and saving them from dependency by helping them receive income, has the potential to create a new logic, an alternative to the patriarchal mentality. In this paper, the issue of whether microfinance practice is an effective project in reducing women's poverty and raising their socioeconomic status will be dealt with, substantiated by interviews with 100 women in total who benefited from microfinance in Diyarbakır. According to the results of the research, the loans borrowed are being used for maintaining an existing business, paying for debts or covering urgent needs, rather than in setting up new businesses. The businesses carried out by women using such loans are not secure businesses with regular income, which would integrate them into public life, but are of a traditional and home-based production nature. The levels of income earned by such businesses are very low and fail to go beyond the status of extra income for the family. Ensuring women with access to loans and providing an increase in income levels of the family do not alone create a change in womens social status.

Keywords: Micro Finance, Neo-Liberal Development Paradigm, Women's Empowerment

\footnotetext{
* Yrd. Doç. Dr., Adnan Menderes Üniversitesi, Fen-Edebiyat Fakültesi, Sosyoloji Bölümü, Aydın, obalkiz@adu.edu.tr

** Sosyolog, Adnan Menderes Üniversitesi, Fen-Edebiyat Fakültesi, Sosyoloji Bölümü, Aydın, ozturk_esra@hotmail.com.tr
} 


\section{Giriş}

1980 sonrasında, yoksulluğun azaltılması ve sürdürülebilir sosyo-ekonomik gelişmeyi temin etmenin bir yolu olarak görülen mikro finans uygulamalarının popülerliği bir hayli artmıştır. 21. yüzyılın ekonomik ve sosyal gelişme anlayışı açısından 'yeni bir paradigma' olarak da tanımlanan (Rahman, 1999, 68) mikro kredi projesi [Mikro finans ve mikro kredi projeleri arasında büyük farklılıklar olmamasına rağmen, mikro finans uygulamaları mikro kredinin yanı sıra tasarruf ve sigortacılık gibi diğer finansman faaliyetlerini de kapsamaktadır. Biz bu makale kapsamında yalnızca mikro kredi uygulamaları üzerinde odaklanacağız. Alan çalışması kısmında ise TGMP (Türkiye Grameen Mikro Kredi Programı)'nın Diyarbakır'da yürüttüğü uygulamaları esas alarak veriler sunmaya çalışacağız] özü itibariyle 'yoksulluğun azaltılması', 'finansal sürdürülebilirlik' ve 'kadınların güçlendirilmesi' gibi üç temel gerekçeye dayalı olarak kurumsallaştırılmıştır. Başlangıcı itibariyle Bangladeş'e dayanan ve 1970'lerde kırsal yoksulluğu/ yoksulları hedef alan mikro kredi programları, günümüzde Güney/Güneydoğu Asya, Afrika ve Lâtin Amerika'daki müşterileriyle küresel bir yoksulluk karşıtı uygulama durumuna gelmiştir. Programın bu denli yaygınlaşmasında esas olarak küresel politik/ekonomik dönüşümler ve bunların dayattığ 1 'küresel/neo-liberal gelişme anlayışı' temel oluşturmaktadır. 1990'larda niteliksel bir dönüşüme uğrayarak hedef kitlesini kırsal yoksullardan, yoksul/dar gelirli kadınlara doğru kaydıran, faiz oranlarını piyasadaki bankaların üzerine çıkaran ve artık sosyal yardımdan ziyade borç vermeyi amaç edinen mikro kredilerin finansal sürdürülebilirlik misyonu öncelikli hale gelmiştir (Simojoki, 2003, 50). Bu dönüşümde bazı yazarlar dünya çapındaki neo-liberalizasyon sürecine ve az gelişmiş ülkelerde uygulanan yapısal uyum programlarının sonuçlarına (Rankin, 2001; Simojoki, 2003; Isserles, 2003) atıfta bulunmaktadir.

Önemli bir diğer nokta, yoksul kadınların krediye erişimlerini sağlama hedefinde olan mikro kredi programlarının kadınları sosyo-ekonomik bakımdan 'güçlendirdiği' tezidir. Kadınları ekonomik hayatın içine sokarak bağımsız kazanç elde etme kapasitelerini arttırmayı hedefleyen program, bu yolla kadınların aile içi konumlarında da değişim olacağını varsaymaktadır. Kredi ve borçluluk ilişkisi çerçevesinde gruplar halinde organize olan kadınların, kolektif bilinçlerinin ve kolektif eylem kapasitelerinin artacağ 1 , nihai olarak da toplum içinde sosyo-ekonomik ve politik açıdan güçlenecekleri ileri sürülmektedir.

Mikro kredi uygulamalarına ilişkin Türkçe literatürdeki çalışmalara bakıldığında, mikro kredilerin yoksulluğu azaltma ve hanenin ekonomik açıdan güçlenmesine olan etkilerine dair ya da finansal açıdan mikro kredi modelinin sürdürülebilir olup olmadığına ilișkin araștırmalar dikkat çekmektedir. Ancak 'güçlendirme' söylemiyle kısmen de olsa feminist özgürleşim dilini kullanan mikro kredi programlarının, kadınlar özelindeki etki ve sonuçlarının ele alınması önemli görülmektedir.

$\mathrm{Bu}$ makaledeki temel amaç, mikro kredi programının 'kadınları güçlendirme' söylemini eleştirel açıdan ele alarak, kredi kullanan kadınların aile ve toplum içindeki ekonomik ve sosyal konumlarındaki değişimleri analiz etmeye çalışmaktır. Bu bağlamda teorik kısımda mikro kredi programı öncelikle küresel/neo-liberal dönüşümler çerçevesinde ele alınmış, programın cinsiyetçi yönü irdelenmiş ardından güçlendirme konusu değerlendirilmiştir. Daha sonra mevcut teorik çerçeve, TGMP (Türkiye-Grameen Mikro Kredi Programı)'nin Türkiye'deki ilk uygulama alanı olan Diyarbakır'da toplam 100 kadınla görüşülerek gerçekleştirilen alan çalışması verileriyle desteklenmiştir.

Mikro kredi projesinin hane yoksulluğunun azaltılması ve kredi kullanan kadınların sosyoekonomik bakımdan güçlendirilmeleri bağlamındaki etkilerini ele alabilmek amacıyla tasarlanan alan çalışması, 2011 yılı Temmuz-Ağustos aylarında Diyarbakır'da gerçekleştirilmiştir. Ancak bu makale kapsamında mikro kredi projesinin yalnızca sosyo-ekonomik güçlendirme bağlamındaki etkileri ele alınmıştır. Diyarbakır, 2003 yılında uygulamaya konulan mikro kredi projesinin 
Türkiye'deki pilot bölgesi olması itibariyle önem taşımaktadır. 90'l1 yıllardan bu yana aldığ yoğun göçlerle işsizlik, yoksulluk ve enformel ekonominin yerleşiklik kazandığı kentte, ataerkil kültürel yapının kıskacında kalan kadınların sorunları da irdelenmesi gereken bir başka konudur. Y1llardır bölgede hakim olan cinsiyetçi norm ve değerler, kadınların sosyal, ekonomik, politik ve eğitsel kaynaklara erişimlerini büyük ölçüde sınırlandırmış olduğundan kentteki yaygın yoksulluktan en çok kadınlar nasibini almaktadır. Kadın odaklı mikro kredi projesinin bu bakımdan Diyarbakır'daki faaliyetlerinin analiz edilmesi anlamlı olmaktadır.

Araştırmanın gerçekleştirildiği Kayapınar, Bağlar ve Suriçi bölgeleri merkez ilçe statüsündedirler. Araştırma yapılması için bu bölgelerin seçilmesinin sebebi, sosyo-ekonomik düzeyi düşük, yoğun göç alan ve yoksulluğun yoğunlaştığı bölgeler olmalarıdır. Kayapınar ilçesi sosyoekonomik bakımdan diğer iki ilçeye göre daha iyi konumda görülebilirken yoksul semtleri de mevcuttur. Ayrıca mikro kredi uygulamasının ilk kez Suriçi ilçesinde başlatılmış olması ve daha sonra diğer iki bölgede yoğunlaşması, bu bölgelere yönelmede etken olmuştur.

\section{Mikro Kredi Programları}

İlk kez Kırsal Bangladeş’te Grameen Bank tarafindan başlatılan mikro kredi projesinin özü, küçük ölçekli/mikro girişimcilere, bir girişimde bulunmaları ya da yatırım yapmaları için küçük miktarlarda ödünç para vermeye dayanmaktadır (Simojoki, 2003, 50). 1950'lerden 80'lere kadar bu türden küçük krediler tarım alanında daha çok geçerliyken, 1980'lerden bu yana ana odak, tarımsal olmayan mikro girişimcilere özellikle de kadınlara doğru kaymıştır. İlk kurumsallaşma dönemlerinde kredi sistemi, sosyal bazı amaçları içermekteydi. Bunlardan en önemlisi kronik yoksulluğu hafifletmekti. Diğer amaçlar sosyal koruma, istihdam oluşturma, mikro ekonominin sürdürülebilir gelişmesini destekleme ve bu sayede makro gelişmeye ve istihdamın iyileşmesine katkıda bulunmaktı. Genel anlamda mikro finans sisteminin amacının finansal problemlerin üstesinden gelebilmeleri ve paralarının yönetimini kolaylaştırmak amacıyla bireysel girişimcilere destek olmak olduğu belirtilmektedir. Ancak temeldeki mantık sosyal ve ekonomik açıdan kırılganlıklarını azaltmak suretiyle yoksul insanlara yardım etmektir. Hatta gelişmekte olan ülkeler açısından mikro finans kuruluşlarının 'sosyal gelişme ajanları' olarak hizmet ettikleri ileri sürülmektedir.

Krediler kişiler yerine gruplara verilmektedir, faiz oranları genellikle ticarî bankalardan yüksek, ancak yoksulların borç aldığı tefecilerden daha düşüktür, kullanıcılar krediyi belirlenen faaliyet için almakta, borçlarını zamanında ve tam olarak ödemekle yükümlü tutulmaktadırlar (Baltacı, 2011, 55). Üyeler aynı zamanda tasarruf yapmaya zorlanmaktadır. Dayanışma grupları mikro kredi programlarının gerekli bir bileşeni olup gruplar vasıtasıyla eksik olan bilgi ve yaptırım mekanizması tamamlanmaktadır. Bu koşullara rağmen yoksul girişimciler için sermayeye erişimin kredinin maliyetinden çok daha önemli olduğu dile getirilmektedir

\section{Neo-liberal İdeoloji, Finansal Sürdürülebilirlik ve Mikro Krediler}

Mikro kredi projesini son yirmi yıllık süreçteki küresel/neo-liberal dönüşümlerden, bunların az gelişmiş ülkelere yansıması olan yapısal uyum programlarından ve yeni gelişme modellerinden yalıtarak analiz etmek mümkün değildir. Sermayenin küresel hareketliliğine paralel olarak özelleştirme, serbestleştirme (liberalizasyon) ve esnekleştirme gibi neo-liberal politika ve uygulamaların küresel düzeyde yarattıkları firsatlar kadar, derinleştirdikleri risk ve eşitsizlikler de yoğun olarak tartışılmaktadır. Isserles'e $(2003,41)$ göre, Yapısal Uyum Programları (YUP), pek çok Üçüncü Dünya Ülkesi tarafindan Dünya Bankasından ve Uluslararası Para Fonundan (IMF) alınan borçlar üzerinden yürütülmekte ve borçlu ülkelerde ulusal sanayinin özelleştirilmesini, piyasaların yabancı sermayeye açılmasını ve paranın değerinin düşürülmesini gerekli kılmaktadır. Bu durum küçük işletmelerin, tarım arazilerinin (buna bağlı tarım ve hayvancılığın) ve formel sektörde kayıtlı işlerin ve gelir olanaklarının tasfiye edilmesine karşın, enformel ekonomi- 
nin etkin biçimde genişletilmesi sonucunu beraberinde getirmektedir. Tam bu noktada mikro kredi projesi gelişmemiş ülkeler açısından küreselleşme/neo-liberalizasyon sürecindeki işsizlik, eksik istihdam, düşük ücretli işler ve büyüyen yoksulluğun yarattığ 1 sorunlarla baş etmede etkin bir araç olarak görülmektedir.

Mayoux'un $(1995,25)$ da belirttiği gibi, 'kadınların mikro-girişimlerine dayalı bu yeni gelişme mantığının son dönemdeki yükselişinde rahatsız edici taraf, bunun devletin küçültülmesi, refah harcamalarının azaltılması ve emek üzerindeki korumaların kaldırılması gibi icraatlere dayalı neo-liberal piyasa reformu bağlamında gerçekleşmesidir' Krediden faydalananlar ise istikrarlı formel sektör istihdamı yaratılmasından daha ziyade yoksulluğa getirilecek potansiyel çözümlere ilgi göstermektedir (Isserles, 2003, 42).

2000'li yılların gelişme mantığ yapılanmadan çıkarak piyasa mekanizmasını merkeze koyan neo-liberal bir yapılanmaya evrilmiştir. Yeni gelişme anlayışında piyasa mekanizması ekonomik ve sosyal gelişmenin garantisi sayılmaktadır. Bu çerçevede işsizlik, yoksulluk, ekonomik eşitsizlik gibi makro ekonomik sorunların çözümünde devlet ve benzeri kurumsal mekanizmalar değil, piyasa aklı etkin olmakta ve adı geçen sorunlar 'yönetilebilir/sürdürülebilir' duruma getirilmektedir.

Ekonomik bireyselciliği esas alan neo-liberal gelişme gündemi, en çok öz-güven, girişimcilik, ekonomik bağımsızlık ve verimlilik temaları üzerinde durmaktadır (Isserles, 2003: 43). Örneğin piyasa herkese eşit firsatlar sunmaktadır ancak bu firsatlara erişebilmek için bireysel edinimlerin arttırılması zorunludur. O halde insanlara doğru araçlar özellikle kurs, eğitim ya da gerekli olduğu durumlarda krediye erişim gibi sosyal sermayeler sunulduğunda, ekonomik bakımdan başarılı olabilmeleri mümkündür. 'Eşit fırsatlar' retoriğinin hâkimiyeti, piyasayı 'demokrasinin fonksiyonel karşılığı' haline getirmektedir.

Mikro kredi uygulaması neo-liberal gelişme gündemine yerleştirildiğinde, şöyle bir çıkarımla karşılaşılabilir. Eğer yoksul birey ve ailelerin krediye erişim imkânı sağlanır ve kendi işlerini kurarak -girişimci olarak- yoksulluk döngüsünden çıkmaları temin edilebilirse, yoksulluk sorunu da kökten çözülecektir. Yoksullara verilen kredi burada bir sosyal yardım değil, faize endeksli bir borçtur. Neo-liberal gündem, yardımları bağımlılık yaratmakla özdeşleştirmekte, mikro kredi gibi bir uygulamanın yoksulluk sorununu çözebilecek bir öz-güven ve ekonomik bağımsızlık reçetesi olduğunu ilân etmektedir. Yoksulluk burada nakit akışını güçlendirerek tedavi edilebilecek geçici bir durum olarak görülmekte, yoksulların kredi gibi bir fırsata erişimleriyle, gelişmiş dünyanın insanları arasına katılabilecekleri düşünülmektedir (Isserles, 2003, 44).

Ancak toplumun yoksul ve mağdur kesimlerini (yoksul kadınları) borç yükü altına sokarak onlardan 'girişimci' yaratmak ve hatta bu yolla yoksulluktan kurtulacaklarına inanmak olası görünmemektedir. Buğra'ya $(2007,1)$ göre, girişimcilik, sermaye ve emek gücünden daha kıt bir kaynak olarak yalnızca küçük bir miktar krediyle üstesinden gelinebilecek bir durum değildir. Ayrıca mikro kredi literatüründe, 'kredi risklerini en iyi üstlenen müşteriler' olarak tanımlanan yoksul kadınlar, aslında bir hayat belirsizliği içindedirler ve yarının kendileri ve ailelerine ne getireceği meçhuldür. Bu kadınları borçlandırarak onlardan 'rasyonel ekonomik bir girişimci' yaratmak makul görünmemektedir.

Mikro kredi uygulamasının en güçlü dayanağı ve bu uygulamanın en temel başarı kriteri finansal sürdürülebilirliktir. Özellikle 1990'larda mikro kredi programının amaçları ve hedef kitlesindeki niteliksel dönüşümün, küresel sermaye hareketliliğindeki artışla, ulusal ekonomilerin liberalleşmesi ve finansallaşmasıyla ilgisi büyüktür. Rankin (2001, 21), bu durumu şöyle açıklamaktadır, devlet güdümlü gelişme mantığından piyasa güdümlü gelişmeye geçiş, devletin rollerini değişime uğratmıştır. Devletler yeni ortamda varlıklarını devam ettirmek ve küresel rekabet gücü elde etmek istiyorlarsa, ulusal ekonomilerini, sermaye akışına açmak ve piyasaların rekabetini kolaylaştıracak şekilde kuralsızlaştırmak ve liberalleştirmek zorundadırlar. Dev- 
letlerin piyasa kurallarına, özellikle de finans bağlamında gittikçe artan oranda teslimiyeti, ulusal gelişme projelerinin finansal rasyonalizasyonla yer değiştirdiği gizli bir 'finansal ortodoksi' yaratmaktadır. Yazara göre, 1970'lerde bir kırsal finansman modeli olarak uygulanan mikro krediler sübvanse edilmekteydi, refah yönelimliydi ve kırsal yoksullar/küçük çiftçiler açısından bir sosyal yardım niteliği taşımaktaydı. 1990'lardaki yapısal uyum programlarıyla birlikte kırsal finansın içi boşaltılmış ve kırsal gelişme plânının yerini neoliberal ortodoksiyle tutarlı bir program almıştır. Yeni programda kırsal yoksullar değil, kadın borçlular yoksulluğu azaltmada hedef haline getirilmiştir.

Yeni dönemde finansal sürdürülebilirlik, Grameen Bank'ın ve Dr. Muhammed Yunus'un gündemindeki en önemli konudur. Yunus'a göre 'sürdürülebilir bir sistem, ancak üyelerinin sorumluluk yüklenmeleri üzerine inşa edilebilir'. Bu kabul de bankaların mikro kredi programlarını maliyetin geri dönüşümü ve kâr elde etme temelleri üzerine kurmalarıyla sonuçlanmaktadır. Yapılan çeşitli saha araştırmalarında Grameen Bank'ın verdiği kredilerdeki faiz oranının \% 20 'lerde olduğu saptanmıştır. Bu tablo mikro kredinin yönetiminin tamamen işletme yönetimine benzer şekilde gerçekleştirildiğini ve kapitalizmin girişimciye faiz yükü getiren ve girişimcinin yaptığı yatırımdan kâr sağlayan niteliğinin aynen benimsendiğini göstermektedir (Rahman, 1999, 78-79). Bankanın temel hedefi finansmandır çünkü finansal sürdürülebilirlik, çeşitli kuruluşlardan gelen fonlara yaslanmak yerine uluslararası finansal piyasalardan gelen fonları büyütebilmeyi zorunlu kılmaktadır. Bu durumda bankaların izleyeceği strateji, portföylerini genişletmek ve yatırımlarını arttırmaktır. Başlangıç amacı 'yoksulun yoksulu'na ulaşmak olan sosyal yardım odaklı Grameen Bank, azalan yardım bütçeleri ve refah karşıtı neo-liberal uygulamalar neticesinde sürdürülebilir borçlular üzerinden kâr sağlamaya yönelmiştir (Mayoux, 2006, 7).

Devlet merkezli bir gelişme paradigmasından piyasa merkezli bir paradigmaya geçiş, mikro kredileri yeni gelişme anlayışının etkin bir aracı haline getirmiştir. Mikro kredi projesini çekici gösteren gerekçeler çeşitlilik gösterse de, projenin belkemiğini neo-liberalizme duyulan güçlü bir ideolojik bağlılık oluşturmaktadır. Ancak bu projeyi biçimlendirmede yalnızca iktisadî bir ideoloji değil, cinsiyetçi bir ideoloji de işbaşındadır. Dolayısıyla projenin ataerkil ideoloji ile bağlantısının ve toplumsal cinsiyet bağlamındaki yansımalarının analiz edilmesi gerekmektedir.

\section{Gelişme Anlayışının Feminizasyonu: \\ Küresel Gelişme Programları Niçin Kadınları Hedefliyor?}

Eylül 2000 yılından bu yana yürürlükte olan Milenyum Gelişme Programı, ülkelerin ekonomik sosyal ve kültürel problemlere ortak çözümler getirmelerini şart koşmaktadır (National Action Plan, 2008, 15). Milenyum gelişme programı yoksulluk ve açlıkla mücadele, tüm insanlar için temel eğitim, toplumsal cinsiyet eşitliği ve kadınların güçlendirilmesi, bebek ve çocuk ölüm oranlarının azaltılması, anne sağlığının korunması, HIV/AIDS vakaları ve salgın hastalıkların önlenmesi ve ekolojik açıdan sürdürülebilir gelişmeye karşıllk gelen hedeflere sahiptir. Türkiye'de de 2008-2013 dönemini kapsayan 'Toplumsal Cinsiyet Eşitliği Ulusal Eylem Plânı' kadınlarla ilgili temel sorunlar olarak siyasete ve genel olarak karar almaya düşük katılım oranı, genç kadınlar arasında yüksek olan ve artmaya devam eden işsizlik ve kadına dönük şiddete dikkat çekmektedir (http://www.undp.org.tr/Gozlem3.aspx?WebSayfaNo=618).

1980'ler özellikle cinsiyete duyarlı gelişme politikasının kurucularından gelen büyük baskıları gündeme taşımıştır. Kadın konulu IV. BM Dünya Konferansı'nda kadınların güçlendirilmesi ve cinsiyet eşitliği, tüm insanlık açısından politik, sosyal, ekonomik, kültürel ve çevresel güvenliğin ön koşulu, sürdürülebilir kalkınmanın da önemli bir parçası kabul edilmiştir (Goetz, \& Sen, Gupta, 1996, 46-47; Cheston, \& Kuhn, 2002, 14). UNDP, UNIFEM ve Dünya Bankas1 tarafından yapılan araştırmalar, gelişmekte olan ülkelerde cinsiyet eşirsizliklerinin ekonomik büyüme ve gelişmeyi engellediği yönünde sonuçlar ortaya koymaktadır. Örneğin son Dünya 
Bankası raporu cinsiyet temelli ayrımların sözkonusu olduğu toplumların daha derin yoksulluğun, yavaş ekonomik gelişmenin, zayıf bir yönetişimin ve insanların daha düşük yaşam standardının bedelini ödediklerini ifade etmektedir. UNDP, cinsiyeti güçlendirme ölçümleri, cinsiyete dayalı gelişme göstergeleri ve insanî gelişme endeksi arasında sıkı bir korelasyonun olduğunu belirtmektedir. Sonuç olarak cinsiyet eşitliği, gelişme programlarının en önemli parçasını teşkil etmektedir (Cheston, \& Kuhn, 2002, 7).

Kadınları gelişme politikalarına entegre etme çabaları aslında yeni değildir. 1970'lerden bu yana eşitlik sorunuyla ilgilenen feminist teorisyenlerin literatüre soktuğu kadın ve kalkınma iliş̧kisini analiz eden üç ana yaklaşım söz konusudur. Bunlar 'Kalkınmada Kadın (KK)' 'Kadın ve Kalkınma (KvK)' ve 'Toplumsal Cinsiyet ve Kalkınma (TCvK)' yaklaşımlarıdır (Toksöz, 2011, 70). Gelişmeyle modernleşmeyi özdeş sayan KK yaklaşımı, kadınları gelişme süreciyle bütünleştirmek peşindedir. Kadınların finans kaynaklarına, teknolojiye ve gelişmiş hizmetlere erişimlerinin sağlanmasıyla onların üretkenliklerinin arttırılabileceğine ve bu sayede de gelişme sürecinin daha pozitif yönde evrilebileceğine inanç beslenmektedir. Ancak kadınların üretici ve gelir yaratıcı yönlerine vurgu yapan, yeniden üretici taraflarını ise göz ardı eden bu yaklaşımda cinsiyet ilişkileri dikkate alınmamıştır. Modernleşme teorisinin eleştirisinden doğan ve bağımlılık okuluna yakın olan KvK yaklaşımı ise KK'nın geliştirilmiş eleştirel bir versiyonudur. Kadınların üretken rolleri üzerinde durur. Toplumsal cinsiyet rolleri sorgulanmaz. 1980'li yıllarda TCvK yaklaşımı ile 'kadın' kavramının yerini 'cinsiyet' kavramı almıştır. Cinsiyet kavramı erkek ve kadın arasındaki güç ilişkilerini analiz etmede daha iyi bir araç durumundadır. Bu yaklaşım, üretici ve yeniden üretici, özel ve kamusal gb. farklı alanlarda kadınların yaşamlarını ele almakta ve kadınların kredi, eğitim ve toprak gibi üretken kaynaklara erişimini incelemektedir. Gelişme geleneksel bir tarzda ele alınmamakta ve ekonomik gelişmeyle özdeş tutulmamaktadır (Simojoki, 2003, 15, 19).

UNDP, BM ve Dünya Bankası gibi yardım kuruluşlarının çoğunun cinsiyet ve gelişme stratejilerinde mikro krediler önemli bir rol üstlenmeye başlamıştır (Cheston, \& Kuhn, 2002, 7). Yoksulluğun azaltılması yönünde kadınların işletilebilir ve pazarlanabilir nitelikteki üretken değerlere (özellikle toprak, sermaye ve kredi-finans-gb) erişimlerinin arttırılmasını sağlayan programlar büyük önem taşımaktadır. Kredi veren kuruluşların bakış açısıyla kadınlara sermaye ve eğitim vermek suretiyle mikro finans, kadınların üretken kapasitesinin harekete geçmesini, yoksulluğun azaltılmasını ve ekonomik verimliliğin arttırılmasını sağlayabilir. Kadınların finansal hizmetlere, kendilerini geliştirme konusundaki yardımlara ve eşit haklara haiz olmaları, insan olarak sahip olmaları gereken doğal haklar konumundadır, ancak bu hakları elde ederek topluma yapabilecekleri potansiyel katkılar da kayda değerdir

Kadınları gelişme programlarının merkezine yerleştirmek ya da gelişme politikalarını cinsiyetlendirmek, kuşkusuz önemlidir ve kadınlar açısından bazı ilerleme olasılıklarını besleyebilir, ancak kadınların çeşitli programlarda niçin 'hedef grup' olduğunun irdelenmesi cinsiyet merceğini gerekli kılmaktadır. Çünkü kadınların ana akım gelişme politikalarına dâhil edilmesi çoğu zaman kadınların aile ve toplum içindeki ikincil konumlarını ve cinsiyete dayalı tâbiyet ilişkilerini yeniden üretici tarzda işlemekte ve kadınların güçlendirilmesi hedefi ekonomik verimlilik yolunda feda edilebilmektedir.

\section{Mikro Kredinin Sadık Borçluları Kadınlar}

Bangladeş’teki ilk faaliyetlerinden bu yana Grameen Bank, yoksulluğu azaltma konusunda kadın kullanıcılara yalnızca borç vermeyi tercih etmekle kalmamış, 1980'lerin ortalarından bu yana öncelikli olarak kadınlar üzerinde yoğunlaşmıştır. Kredilerin kadınlara odaklanmasında bazı sebepler söz konusudur ki bunlardan ilki 'kadın yoksulluğu'dur. Gelişmekte olan ülkelerde yoksulluk kadınsılaşmaktadır. Dr. Yunus'un deyimiyle kadınlar 'yoksulun yoksulu' durumunda 
olan kitlelerdir. DB verilerine göre, bu ülkelerde işsiz kesimin büyük çoğunluğunu kadınlar oluşturmaktadır (Baltacı, 2011, 61). Kadınlar çalışsalar da oldukça düşük ücretli işlerde, enformel sektörde örgütsüz olarak ya da ev eksenli ve parça başı işlerde çalışmaktadır. Bu model ev dışına çıkmadan, kadının geleneksel rollerinin aynen sürdürüldüğü buna ek olarak ücretsiz ev-içi üretimin de kadın tarafından gerçekleştirildiği bir modeldir.

İkinci sebep, kadınların aile içinde ve toplumda ekonomik bağımsızlıklarını kazanabilmek için çok zayıf olasılıklara sahip olmaları gerçeğidir (Simojoki, 2003, 55). Kadınların üretken bazı kaynaklara erişimlerinde esas engel teminat koşulu olmaktadır. Çünkü mülk sahipliği olgusal ya da yasal olarak kadınlar için çok zordur. Diğer bir engel, işyeri kurmak ve ekonomik faaliyeti başlatmaya ilişkindir. Çok düşük düzeydeki geçim koşullarından kaynaklanan başlangıç sermayesinin yokluğu, finansal kararlar üzerindeki ataerkil kontrol, girişimcilik, piyasa bilgisi, yönetimsel ve teknik yetilerin olmayışı ve ev içi sorumluluklardan kaynaklı zaman yokluğu, kadın girişimciliğinin önündeki tipik engellerdir. Bu açıdan bakıldığında mikro kredilerin kullanıcıdan teminat istememesi ve kredi işlemlerinin neredeyse sıfır bürokrasi ve prosedürle yürütülmesi yoksul kadınlarca cazip bulunmaktadır.

Üçüncü sebep kadınların aile refahına daha çok katkı sağladıkları varsayımıdır. Dr. Yunus'un ifadeleriyle 'kadınların kendileri, çocukları evleri ve evin rızklyla ilgili plânları vardır'. Kadınların gelirleri arttıkça bunun çoğunu ailenin geçimi için kullandıkları daha azını kişisel tüketimleri için harcadıkları düşünülmektedir (Isserles, 2003, 48). Erkekler genelde işe yatırım yaparken kadınların aileye yatırım yaptığ 1 kadının gelirindeki herhangi bir yükselişten bütün aile üyelerinin faydalandığı kaydedilmektedir. Bu bakımdan kadına doğru yönlendirilmiş kaynakların yoksulluğu sınırlandırmada, erkekler yönündeki kaynaklardan daha etkin olacağı beklenmektedir (Simojoki, 2003, 54, 55).

Bu varsayım Isserles'e $(2003,48,54)$ göre, cinsiyetçi ideolojiyi beslemektedir. 'Kadınlar gelirlerini aileleri için, erkeklerse kendileri için harcarlar' yönündeki kabul, kadınların ve erkeklerin toplumdaki cinsiyet rolleri ve sorumluluklarına dair geleneksel ve ataerkil kavramları yeniden üretmektedir. 'Erkeklerin hepsi aynıdır ve böyle kalacaklardır' zihniyetiyle hareket edildiğinde, erkeklerin davranış modellerinin aile için zarar verici olduğu teslim edilmekte, ancak bunlar kaçınılmaz addedilip rasyonelleştirilmeye çalışılmaktadır. Cinsiyet rollerine bu şekildeki bir yaklaşım, kadınların baskı altında tutulmasını meşrulaştırmaktadır. 'Anne' olarak idealleştirilen kadınların omuzlarına yeni yükler binmekte ve kadınlığa ilişkin geleneksel kültürel kavramlar güçlendirilmektedir. 'Kadınlar ailenin moral koruyucusudurlar ve serkeş erkeklerin polisidirler'.

Kredilerin kadınlara odaklanmasındaki son sebep ise verimlilik ve sürdürülebilirliktir. Mikro kredi literatüründe 'en sadık borçlular' olarak tanımlanan kadınların kredi geri dönüş oranları çok yüksektir. Finansal sürdürülebilirlik açısından kadınların işbirliğine daha yatkın olduğu belirtilmektedir. Mikro kredinin açık gündemi yoksul kadınlara borç vermeyi, onları sosyo-ekonomik bakımdan güçlendirmek, yoksulluk döngüsünü kırmak ve toplumun gelişmesine katkıda bulunmak gerekçeleriyle meşrulaştırmaktadır. Ancak gizli gündem farklı şekilde işlemektedir. Kadınlara odaklanmak, bankanın yatırımlarına ve kredilerin geri dönüşüne ilişkin hedeflerinin başarılmasında stratejiktir. Rahman'a $(1999,69)$ göre, 'kredi borçlarının ödenmesinde erkeklerden para koparılmasının bir hayli zor olması, oysa kadınların daha kolay yönetilebilir olması' burada kilit noktadır. Alanda erkek üyelerle çalışmak, toplantılara gelmemeleri, banka çalışanlarıyla tartışmaları ve hatta onları tehdit edip korkutmaları yüzünden çok zordur. Kadınların toplumdaki hassas konumları ise onları sadık borçlu haline getirmektedir. Şöyle ki, kadınların fiziksel hareketlilik fırsatları düşük düzeydedir bu yüzden kadınlar kolaylıkla izlenebilir. Kültürel açıdan modellendirilmiş davranış örüntüleri (utangaçlık, pasiflik ve itaatkârlık) ise onları daha güvenilir kılar ve disiplin altına alınmalarını kolaylaştırır. Geri ödeme oranlarının bu kadar 
yüksek oluşu, kadınların kendilerini gerçekten sorumlu hissetmelerinden değil, onların buna zorlanmalarından ileri gelmektedir. Gerek banka yetkililerin uyguladıkları formel baskılar gerekse de dayanışma gruplarından gelen informel baskılar sayesinde kadınlar kolaylıkla sindirilebilmektedir.

Geleneksel toplumlarda kadınlara atfedilen iffet ve saflık özellikleri onları kırılgan hale getirmektedir (Rahman, 1999, 70). Yazarın görüşüne göre, taksit ödemelerinde sorun yaşayan kadın diğer grup üyeleri ve banka çalışanlarınca sözel saldırılar yoluyla aşağılanabilmektedir. Kamusal alanlarda kadının bu şekilde aşağılanması ailede ve akrabalık grubunda kocanın itibarının zedelenmesi anlamını taşımaktadır. Borçlu bir erkeğin bankada rehin bırakılması önemli görülmeyebilir. Ancak aynı durum bir kadın için sözkonusu olursa durum kesinlikle farklılaşır. Bu bakımdan aile üyeleri kadınların taksit ödemelerini zamanında yapmaları için çabalamaktadır. En temel kaygısı finansal sürdürülebilirlik olan mikro kredi projesinde kadın, 'en sadık ödeyici' olduğu için önemsenmektedir. Bu da kredinin işletilmesinde geleneksel cinsiyet ilişkilerinin devreye sokularak ataerkil ideolojinin nasıl güçlendirildiğini gözler önüne sermektedir.

\section{Kredilendirilen Kadın ‘Güçlendirilen’ Kadın mı?}

Dünya çapında mikro kredi kullandıran organizasyonların amaçlarına bakıldığında 'kadınları güçlendirme' söylemi ağırlıktadır. Mikro kredi programının popülerliği de bu programın kadınların ekonomik, sosyal ve politik açıdan güçlenmelerini sağlama potansiyeline sahip olduğu varsayımına dayanmaktadır.

Güçlendirme, dünya çapında pek çok mikro finans kuruluşunun açık değilse de örtük amacı durumundadır. Ancak güçlendirme tam olarak neyi ifade etmektedir? (Cheston, \& Kuhn, 2002, $12,17)$. UNIFEM'e göre güçlendirme, 'tercih üretebilme ve pazarlık gücünü kullanabilme becerisini kazanabilmektir'; 'Bir öz-saygl duygusu gelişstirebilmek, istenilen değişimleri gerçekleştirebileceğine duyulan inanç ve birinin kendi yaşamını kontrol edebilme hakkl'dır. Güçlendirme, 'değişim', 'tercih' ve 'güç' le ilgilidir Kadını güçlendirilmiş sayabilmek için yaşamında stratejik seçimler yapabilmesi için gerekli maddî, insanî ve sosyal kaynaklara erişimi gereklidir. Kadınlar tarihsel bakımdan kredi, mülkiyet ve para gibi yalnızca maddi kaynaklara erişimde dezavantajlı konumda olmakla kalmamış, eğitim ya da ticarî bilgi gibi sosyal kaynaklardan da dışlanmıştır. Ancak kaynaklara erişim yalnız başına otomatik olarak güçlendirme ya da eşitlikle sonuçlanmamaktadır. Çünkü kadınlar amaçlarına ulaşabilmek için kaynakları kullanabilme becerisine de sahip olmalıdırlar. Güçlendirme süreçleri kültürden kültüre değişim göstermekle birlikte kadınların güçlenmesinde en önemli göstergelerden bazıları, karar alma sürecine artan katılım, kadının aile ve toplumdaki daha eşitlikçi statüsü, politik güç ve haklardaki artış ve artan öz-saygıdır.

Mikro kredi projesini biçimlendiren üç temel paradigmanın mikro krediye ve cinsiyet konusuna bakış açıları ile politika öncelikleri birbirinden farklıdır (Mayoux, 2006, 6). 'Finansal sürdürülebilirlik' ve 'yoksulluğu azaltma' yaklaşımında güçlendirme, kadınlar açısından temel hedef durumunda değildir. Her iki yaklaşımda da gelişmeye bakış, toplumsal cinsiyet odaklı değildir, dolayısıyla da güçlendirme amaç değil, araç konumundadır. İlk yaklaşımda kadınların mikro finansa erişiminin artışı, başka herhangi bir müdahaleye gerek kalmadan kadınların ekonomik açıdan güçlendirilmesiyle son bulacaktır. İkinci yaklaşımda ise artan refah ve grup yapısı otomatik olarak kadınları güçlendirecektir. 'Feminist güçlendirme' paradigması ise kapitalizmin sosyalist-feminist eleştirisinden hareket ederek kadınların güçlendirilmesini kendi içinde bir değer olarak görür. Cinsiyete dayalı tâbiyet, kadınların yaşamlarının tüm yönlerini etkileyen, karmaşık ve yaygın bir süreç olarak değerlendirilir. Bu yüzden kadınların güçlendirilmesi daha geniş çaplı sosyal dönüşümün aslî ve bölünmez bir unsuru olarak düşünülmektedir. Ekonomik güçlendirme bireysel temelde ele alınmaktan daha ziyade mülkiyet hakları, aile içi 
ilişkilerdeki değişim ve makro-ekonomik bağlamın dönüşümü gibi konuları içermektedir. Mayoux'a göre bu yaklaşım ilgileri doğrudan kadınların cinsiyet konuları etrafında örgütlenmesine yöneltebilen yegâne paradigmadır.

Feminist güçlendirme paradigması mikro finans uygulamalarını kadınların ekonomik, sosyal ve politik açıdan güçlendirilmelerinde bir başlangıç noktası kabul eder toplumsal cinsiyet kaynaklı güç ve tâbiyet ilişkilerinin tüm toplum kesimlerinde dönüştürülmesini hedefler. Mikro kredi programı içerik itibariyle feminist güçlendirme ve dayanışma dilini sıklıkla kullanmaktadır ancak programın sosyal etkileri ve cinsiyete dair uzantıları hususunda bir belirsizlik ve karmaşa sözkonusudur. Kadınların kredi ve gelir kaynaklarına erişimi ve kredi borçlarının yüksek oranlı geri dönüşü, programın finansal başarısının göstergeleri sayılmaktadır. Ancak uluslararası kuruluşların toplumsal cinsiyet eşitliği politikalarının bir ürünü sayılabilecek mikro kredinin toplumsal cinsiyet eşitsizliği ve tâbiyet ilişkileriyle mücadeledeki konumu ve gerçek bir güçlendirmeye kaynaklık edip edemediği sorgulanmalıdır.

Kadınların mikro krediyle bağlantılı olarak ekonomik açıdan güçlendirilmeleri konusunda, a) kredi kullanmaya karar verme süreci b) kredinin aile içindeki kullanım modeli c) kredinin istihdam sağlayıcı-gelir arttırıcı bir girişime yatırılıp yatırılmadığ 1 d) kredi kullanarak yapılan işin niteliği e) aile içinde paranın kontrolünün kimde olduğu f) kredinin geri ödeme modeli ve yeniden borçlanma g) kredi ile yapılan işten kâr elde etme durumu ve kredinin aile yoksulluğunun azaltılmasında gerçekten etkili olup olmadığı gibi konular mutlaka ele alınmalıdır.

Mikro kredide kadınlar bankadan kredi almaktadırlar ancak çoğu zaman aile içinde bu kredinin nasıl ve kim tarafından kullanılacağı önceden belirlenmiş olmaktadır. Naila Kabeer, kadınların kaynakları etkin biçimde kullanmalarını gerektiren karar alma, görüşme ve manipülasyon süreçlerini tanımlamak için 'ajan' terimini kullanmaktadır. Yaşamlarının büyük bir bölümünde karar alma süreçlerinden dışlanmış olan kadınlar, amaçlarını net bir biçimde belirlemelerini ve bunları etkin bir şekilde gerçekleştirmelerini sağlayan ajanlık konumunu kaybetmişlerdir (Cheston, \& Kuhn, 2002, 13). Rahman'ın (1999, 70, 75) yaptığı araştırmada, kadın kullanıcılar krediyi aile ekonomisine sunmakta ve aile üyeleri bu parayı ailenin önceliklerine uygun şekilde kullanmaktadır. Kredinin bir bölümü gelir arttırıcı faaliyetlerde kullanıl1yorsa da diğer bir kısmı mutlaka ihtiyaçların giderilmesinde harcanmaktadır. Kırsal Bangladeş’te aile işbirlikçi bir birim gibi işlemekte ve kadının aldığ kredinin bu birime aktarılması kredinin gerçek kullanıcısı ya da hak sahibinin teşhis edilmesini sorunlu hale getirmektedir. Örneklemde yeralan kadınların kredi alma kararında kocaları \% 60 oranında belirleyici iken, krediyi kullananlar kategorisinde ise $\% 70$ oranında kocalar yer almaktadır.

Adaman ve Bulut'un $(2007,103,106)$ Diyarbakır'da yaptıkları çalışmada, kredi kullanarak aileye gelir getirmeye başlayan kadınlardan küçük bir kısmının hayatında önemli değişimler olmuş, ataerkil aile yapısı yavaş da olsa çözülmeye başlamış ve kadınların aile içi statüsü yükselmiştir. Ancak pek çok kadın toplumsal koşullar ve aile içi kurallar gereği aldıkları krediyi olduğu gibi kocalarına teslim etmektedir. Gelir getirici iş yapsalar da, kadınların gündelik hayatında hiçbir değişim olmamıştır. Kadınların çoğunlukla ev-içi üretimlerinin ürünlerini satma işlevini de kocalar ya da babalar üstlenmektedir. Yani piyasaya açılma ve pazarlama noktasinda kadın kesinlikle geri konumdadır.

Kullanılan kredilerin gelir arttırıcı-istihdam sağlayıcı bir işe yatırılıp yatırılmadığı ve kadınların gelirlerinde artış olup olmadığı mikro kredinin yoksullukla mücadelesi bağlamında da önem taşımaktadır. Mikro kredilerin gelir üzerindeki etkilerinin aslında değişken olduğu belirtilmektedir. Kredi kullananların çoğunluğu için gelirlerdeki artış ya çok az ya da negatif düzeydedir. Yine pek çok bulgu göstermektedir ki, kadınlar zaten varolan ekonomik faaliyetlerine yatırım yapmaktadırlar, bunlar düşük kârlılık oranına sahip, güvencesiz işler ya da kocalarının işleridir. Hangi faaliyette bulunacakları hususunda kadınların seçim özgürlükleri ve gelirlerini arttıra- 
bilme yetenekleri, yatırım kaynaklarına erişimdeki cinsiyet eşitsizlikleri yüzünden ciddi biçimde sınırlandırılmaktadır. Kadının ailenin ekonomik bakımdan ayakta kalmasında yüklendiği sorumluluklar, ücretsiz ev işlerinin yoğunluğundan kaynaklanan zaman yokluğu, çok düşük düzeyde hareketlilik imkânı, cinsiyetçi baskılar ve cinsel şiddet pek çok kültürde kadının piyasaya açılmasını engellemektedir (Mayoux, 2006, 10). Kredilerin her an ulaşılabilir olmasının, kadınların üretken kaynaklar üzerinde tekel oluşturmuş ataerkil sistemle hesaplaşmaları açısından destek oluşturduğu ancak piyasaya erişimleri noktasındaki katı sosyo-kültürel sınırlamaların kadınların piyasa ile olan ilişkilerini dönüştürmede engel teşkil ettiği dile getirilmektedir (Goetz, \& Sen, Gupta, 1996, 47).

Mikro kredilerde yüksek oranlı geri ödemeler, programın görüntüsel düzeyde başarısıdır. Ancak yüksek düzeyli geri dönüşlerin ne şekilde gerçekleştirildiği çok daha önemlidir. Rahman'ın $(1999,78)$ çalışmasında, köydeki ailelerin kredi taksitlerini kendi kaynaklarından daha ziyade diğer bazı kaynaklardan aldıkları kısa dönemli borçlarla ödedikleri rapor edilmiştir. $\mathrm{Bu}$ borçlar dayanışma grubundaki diğer kadın üyelerden yeni bir borç aldıktan sonra faiziyle geri ödeneceği vaadine dayalı olarak tedarik edilmektedir. Taksitlerin geri ödenmesinin sermayeden, ödünç para alarak ya da yeniden kredi almak yoluyla gerçekleşmesi, kadınları borç döngüsüne sokarak güçsüzleştirmektedir. Simojoki'ye $(2003,52)$ göre, borç içine sokmak suretiyle yoksulları bankaya mahkûm etmek esasında onlara bir tekme vurmaktan farksızdır. Mikro kredinin başarıları nicelikseldir ve finansal araçlar ekonomik ve sosyal problemlerin çözümünde yetersiz kalmaktadır.

Mikro kredi programı verilen borçların geri dönüşünü garanti etmek için maddi teminat yerine sosyal teminat esasına göre çalışmaktadır. Kadınlardan oluşan dayanışma grupları kadınların birbirleriyle karşılaşmaları, taksit ödemeleri ve farklı sosyal gelişim sorunlarını bir arada tartışabilmeleri için bir alan yaratmakla birlikte, son yıllardaki uygulamalarda bu gruplar tamamen alınan krediyi uygun yatırımlarda kullanmanın ve kredi kullanıcılarının taksit ödemelerinde geri dönüşümü sağlamanın bir güvencesi olarak iş görmektedir (Rahman, 1999, 71). Borçlu kadınlar grup içinde kurallara uyma konusunda diğer üyelerden kayda değer bir baskı görmektedirler. Rankin'e $(2001,29)$ göre, dayanışma grupları, yönetsel maliyetleri kısmanın, geri ödemeleri motive etmenin ve yakın bask1 sayesinde finansal bir disipline girmenin mekanizması durumundadır.

Adaman ve Bulut'un $(2007,78,81)$ çalışmasında, Grameen'in finansal sürdürülebilirliğin en temel aracı olarak devreye soktuğu 'grup baskısı', Diyarbakırlı kadınlar arasında gerçek bir 'dayanışma ekonomisi'nin oluşumuna yol açmıştır. Aynı yoksulluk koşullarında birbirlerinin halinden anlayan kadınlar, borçların geri ödenmesinde tam bir yardımlaşma örneği sergilemişlerdir. Alınan borçların geri dönüşü grup baskısı yoluyla değil, borçlarını bir namus meselesi olarak algılayan kadınların dini ve ahlâkî inançları gereği borca sadakatleri sayesinde gerçekleşmiştir.

Ana akım gelişme anlayışında güçlendirme kavramı, kadınları toplumsal hayatın hemen her alanında bağımlı konuma yerleştiren cinsiyetçi güç ilişkileriyle mücadele ederek kadının ikincil pozisyonunu ve tâbiyetini ortadan kaldırmak yerine, girişimcilik üzerinden kadınların bireysel özgüvenlerini tesis etmek anlamını taşımaktadır (Simojoki, 2003, 56). Mikro kredilerin ana akım güçlendirme anlayışından hareketle kadınların esasen ekonomik anlamda güçlendirilmeleri üzerine odaklandığı kabul edilse dahi, bu konuda da yüz güldürücü sonuçlarla karşılaşılamamaktadır. Simojoki, herhangi bir ekonomik girişimde bulunmanın kayda değer düzeyde ağır bir iş yükü ve geri ödeme baskısı dayattığını ancak gelirde küçük bir artış yaratabildiğinden sözetmektedir. Kadınlar, ekonomik girişimleri, piyasa ilişkileri ve gelirleri üzerinde tam kontrole sahip değildirler. Aile içinde çoğu zaman kredinin kullanımında, ekonomik faaliyetin türünün belirlenmesinde ve elde edilen gelirin yönetiminde kadınlar söz sahibi olmamasına 
karşın, borç-taksit ödemelerinin birincil düzeyde muhatabı durumundadırlar Çünkü kredi kadınlara verilmektedir. Başka bazı durumlarda ise kadınların gelirlerinde ve otonomilerinde artış sözkonusu olduğunda erkeklerin hane içi harcamaların karşılanmasındaki katkı ve desteklerinin azalabildiği sonucu elde edilmiştir (Simojoki, 2003, 57,58).

Isserles'e $(2003,48,49)$ göre, kadınları gelir getirici faaliyetlere yöneltmek ve finansal aç1dan desteklemek önemli bir adımdır, ancak onları ekonomik anlamda güçlendirmek, ayrıcalıklı üretken alanlara sokmak anlamını taşımalıdır. Bu hususta cinsiyete dayalı işbölümünden kaynaklanan kültürel pratikler hâlâ etkin olduğundan dolayı kadın güçlenememektedir. Güçlendirme yalnızca gelir arttırımı ile bağlantılandırıldığında kadın emeği, 'gelir kazanan emeğe', konumu ise 'üretken işçi'ye indirgenmektedir. Eğer kadınların evdeki ve dışarıdaki sorumlulukları eşit biçimde paylaşılmıyorsa, kadınların yaşam standartları gerçekten iyileşmiyorsa, 'güçlendirilmiş kadınlar'dan bahsetmek olası değildir.

Sanyal $(2009,530)$, kadınların içinde yeraldıkları daha geniş sosyal ve ekonomik bağlamlardaki cinsiyet eşitsizliklerinde önemli bir değişim olmaksızın mikro finans uygulamalarının kadınların güçlendirilmeleri üzerinde sınırlı etkiye sahip olacağını iddia etmektedir. Güçlendirme, ataerkil kültürde yaşayan kadınlar açısından uzak bir hedef olarak kalmaktadır. Çünkü bu kadınların güçsüzleşmesinde önemli bir faktör yoksullukla bağlantılı ekonomik yoksunluk iken, önemli bir diğer faktör de ekonomik olmayan, ancak kadınların hayat güzergâhını yönlendiren sosyal norm ve pratiklerdir. Genel olarak mikro finans uygulamaları mikro düzeyde kadınların güçlendirilmesi yönünde önemli bir etki yaratabilmekte, ancak makro düzeydeki yapıları değiştirememektedir. Sürece eleştirel bakan teorisyenler, kadınların güçlenmesinde toplumsal cinsiyet ve sınıf ilişkileri hususunda bilinçlendirilmelerinin ve kadın hakları için köklü mücadeleler içinde örgütlenmelerinin büyük önem taşıdı̆̆ fikrindedirler.

\section{Mikro Kredinin Türkiye Macerası}

Özellikle yoksulluk istatistikleri dikkate alındığında mikro kredi uygulaması için büyük bir potansiyele sahip olan Türkiye'de TGMP, yoksulların kendi girişimleriyle yoksulluk çemberinden çıkabilmeleri için resmî finansal sistemin dışına itilen 'yoksulun yoksulu' kadınları hedef alması bakımından bir ilk niteliğindedir. Ancak 1970'lerden bu yana Türkiye'de esnaf-sanatkâr, küçük üretici, çiftçi ve hayvancılar için nakit ihtiyacını gidermek üzere kredi imkânlarının özellikle devlet eliyle seferber edilmesi, yaygın bir uygulama durumundayd. 1980'lerden sonra kredi kuruluşlarının özellikle kadınlara odaklanması akımına paralel olarak Türkiye'de de iki mikro finans uygulamasının hayata geçirildiği görülmektedir. Bunlardan ilki 2002'de KEDEV'in (Kadın Emeğini Değerlendirme Vakfi) kadın girişimcilere sermaye sağlayan yan kuruluşu olarak faaliyete başlayan MAYA Mikro-Ekonomik Destek İşletmesi, ikincisi ise 2003 yılında TISVA (Türkiye İsrafı Önleme Vakfi) ve Grameen Trust işbirliğiyle kurulan TGMP'dir.

TGMP bütün dar gelirlilerin finansal hizmetlere ulaşabildiği ve yoksulluğun olmadığ bir Türkiye oluşturmak hedefiyle hareket ederken KEDEV üretmek ve daha iyi yaşamak için nakit desteğe ihtiyaç duyan kadınları MAYA projesine davet etmektedir (www.tgmp.net, www.eski. bianet.org-04.10.2013). Diyarbakır'da faaliyetine başlayan TGMP, bölgede yıllardır içinden çıkılmaz bir hal almış olan işsizlik ve yoksulluk sorunu için bir kurtuluş reçetesi gibi görülmüş, İstanbul ve Kocaeli'de etkin olan MAYA ise işini geliştirmek ya da yeni bir iş kurmak isteyen kadınlar için sadece yeni bir alternatif durumunda olmuştur.

2003 yılında Diyarbakır'da 2 şubeyle işe başlayan TGMP, 2013 itibariyle 66 ilde toplam 97 şubeyle faaliyetine devam ederek yalnızca Güneydoğu'da değil Türkiye çapında yaygınlaşmıştır. Diyarbakır'da en yoksul 6 kadına kredi vererek başlangıç yapan TGMP'nin 2013 itibariyle 60.553 üyesi ve 53.183 bizzat kredi kullanıcısı mevcuttur. Dağıttığı kredi meblağına bakılırsa TGMP, 2013 Eylül itibariyle 247.002.564 TL. (124.346.461 \$) kredi dağıtmıştır. Sektörel kredi 
dağılımında, \% 35'lik dilim işlem ve üretim alanına, \% 29 dükkânlara, \% 20 iş ve ticarete, \% 7 evcil hayvancılığa, \% 4 hizmetlere, \% 3 Seyyar satılıcılığa, \% 2 ise tarıma gitmiştir. 2013 Temmuz itibariyle toplam kârı ise 589.903.89 TL'dır (www.tgmp.net).

Rakamlar mikro kredinin seyrine ilişkin iyimser bir hava yaratmaktadır ancak mikro kredinin Diyarbakır süreci epeyce zorlu geçmiştir. Yardım geleneğinin çok güçlü olduğu ve halkın karşılıksız bağışlara alışkın olduğu bu bölgede faiziyle ödenmesi gereken krediye alışmak özellikle de kadınlar açısından kolay olmamıştır. Faizle para almak fikri kadınlar için dinsel ve ahlâki anlayışlarına tamamen terstir. 'Hizmet bedeli' kavramıyla faiz konusu meşrulaştırılsa dahi uygulanan faiz oranının piyasadaki bankalara göre bir hayli yüksek olması (\% $15 \mathrm{gb}$.) kadınların haftalık ödemelerini zorlaştırmaktadır. Bu zorluğun üstü başka kaynaklardan borç alarak, dayanışma grupları içinde yardımlaşarak kapatılmaya çalışılmıştır (Adaman, \& Bulut, 2007, 55).

2003 yılında Diyarbakır'da iktidar partisinden bir milletvekilinin girişimiyle başlayan mikro kredi programı iktidarın siyasi bir rant aracı olarak da değerlendirilmiştir. Bölgedeki bazı STK'ların iddiası, kredinin parti yandaşlarına dağıtıldı $\breve{g}$, tanıtımın daha çok partiye potansiyel oy çıkabilecek semtlerde yapıldı ğı, fakat bazı toplumsal kesimlerin sistematik biçimde krediye erişimden dışlandığı yönündedir. Kredi almadan önce geçirilen yedi günlük eğitim sürecinde TGMP'nin on önerisinin Türkçe'leri oldukça zayıf olan kadınlar tarafından öğrenilmesi istense de kadınlar kendi hayat tarzlarıyla pek tutarlı olmayan bu önerileri salt engeli aşmak adına sadece ezberlemişlerdir (Adaman, \& Bulut, 2007, 56,57).

En önemli bir başka nokta ise haftalık geri ödeme baskısı kadınları bilmedikleri alanlara yatırım yaparak risk almaktan uzaklaştırmış ve kadınlar aldıkları kredi ile daha az kazanca razı olarak en iyi bildikleri ve çoğunlukla geleneksel kadın işleri sayılan faaliyetlerini sürdürmüşlerdir. Hatta krediler ilk elde ailenin acil ihtiyaçlarının giderilmesi için çoğunlukla da eşler tarafından kullanılmıştır. Düşük katma değere sahip geleneksel işler piyasada arz fazlası yüzünden kazanç getirmezken, TGMP krediyi kadınlara sunmakta ve 'gerisine karışmamaktadır'. Bu durumda girişimcilik ve piyasanın işleyişi konusunda hiçbir arkaplana sahip olmayan kadınlardan 'başarılı bir girişimci' yaratmak hedefi sorgulanır hale gelmektedir (Adaman, \& Bulut, 2007, 58).

\section{Araştırmanın Amacı Kapsamı ve Yöntemi}

Alan araştırmasındaki temel amaç, mikro kredi uygulamasının yoksulluğun azaltılması ve kadınların güçlendirilmesi bağlamındaki etkilerini ele almaktır. Mikro kredi uygulamalarının pilot bölgesi olan Diyarbakır, bu uygulamalar konusunda 10 yıllık bir geçmişe sahiptir. 2003 yılında üç kadına kredi vererek başlatılan uygulama, araştırma yaptığımız 2011 yılı itibariyle yaklaşık 9000 kadınla sürdürülmekteydi.

Mikro kredi uygulamaları hakkında bilgi edinebilmek ve örneklemi oluşturabilmek için öncelikle TGMP Diyarbakır Şubesinden bilgi alınmıştır. Diyarbakır'da Kayapınar, Bağlar ve Sur bölgeleri olmak üzere üç ana mikro kredi şubesi mevcuttur. Her üç şube de ziyaret edilerek yetkililerden bilgi alınmış ve bu şubelere kayıtlı olarak kredi kullanan kadınların toplam sayısı tespit edilmiştir. Evreni temsil edebilecek şekilde, Suriçinden 33, Bağlar'dan 33 ve Kayapınar'dan 34 olmak üzere toplam 100 kadını içerecek bir örneklem oluşturulmuştur. Örneklemi belirlemedeki ana kriter, mikro kredi kullanımının kadınların sosyo-ekonomik konumları üzerindeki etkilerini daha net ortaya koyabilmek açısından üyelerin en az 2 yıllık kredi kullanıcıs1 olmaları yönündeydi. Bu kritere dayalı olarak kayıtlı üyeler arasından seçim yapılarak ve bu üyelerin tam adresleri alınarak örneklem oluşturulmaya çalışılmıştır. Öncelikle TGMP yetkililerinin üç bölgeye de yaptığı rutin ziyaretlere eşlik edilerek bölgelerin tanınması mümkün olmuş ve pilot uygulamalar gerçekleştirilmiştir. Araştırma sürecinde bahsettiğimiz kritere dayalı 
olarak tespit ettiğimiz adreslerde bulamadığımız ya da bizimle görüşme yapmak istemeyen kadınlar olmuş, bu durumda görüşme yaptığımız diğer kadınların yönlendirmeleriyle yine aynı kritere uyacak şekilde yeni kadın üyelerle görüşmeler gerçekleştirilmiştir. Görüşmeler her gün düzenli biçimde bölgelere giderek evlerde kadınlarla yüzyüze ve soru formu eşliğinde gerçekleştirilmiştir.

Soru formu toplam 58 sorudan oluşmaktadır. Soru formunun ilk bölümü kredi kullanan kadınların sosyo-demografik özelliklerini ortaya koymaya dönüktür. Bu bölümde, yaş, medeni durum, eğitim durumu, doğum yeri, hane büyüklügü, eşin yaptığı iş, eşin kazanc1, hanede toplam kazanç ve sosyal güvence durumu sorgulanmıştır. Ikinci bölümde mikro krediye başvuru süreci ve başvuru kararını sorgulamaya dönük sorular mevcuttur. Üçüncü bölüm ekonomik güçlendirme konusunu ele almaya dönüktür. Mikro kredi ile yapılan işin türü, bu işten elde edilen kazanç miktarı ve kazancın harcama modeline ve mikro kredi sürecinde yaşanan sorunlara ilişkin sorular yeralmaktadır. Dördüncü bölüm sosyal güçlendirme kriterlerini sorgulamaya dönük sorulardan oluşmaktadır. Kadınların aile içi karar alma mekanizmasına katılım düzeyleri, aile içi konumlarında mikro kredi süreciyle birlikte herhangi bir değişim olup olmadığı, kredi alarak bağımsız bir iş yapmanın hayatlarında değişiklik yaratıp yaratmadığı, kadının çalışmasına dair ya da çocukların okutulmasına dair tutumlarında değişim olup olmadığı bu bölümde sorgulanmaya çalışılmıştır.

Her bir kadınla soru formu eşliğinde yapılan görüşmeler yaklaşık bir saat sürmüştür. Görüşmeler esnasında izin alınarak ses kayıt cihazı kullanılmış daha sonra kayıtlar çözülerek bulgular şekillendirilmiştir. Soru formu eşliğinde yapılan bire bir görüşmeler dışında dayanışma grubu üyelerinden her birinin evinde gerçekleşen haftalık tahsilât (kredilerin geri ödemesi) toplantılarından bazılarına da katılarak gözlem yapılmış olması, alan araştırmasının zenginleşmesi açısından faydalı olmuştur. Haftalık toplantılar hem el emeği ürünlerin pazarlanması için bir fırsat, hem de üyelerin çeşitli sorunlarını tartıştıkları bir sosyal paylaşım alanı durumundadır. Her toplantı sonunda mikro kredinin ilke ve sloganları üyelerce ayakta söylenmektedir.

\section{Araştırma Bulgularının Değerlendirilmesi}

\section{a) Kadınlara ve Ailelerine ilişkin Demografik Bilgiler:}

Mikro kredi projesi kapsamında kredi kullanan kadınların yaş dağılımına bakıldığında; \% 35'i 18-25 yaş grubunda, \% 23'ü 26-33 yaş grubunda, \% 22'si 34-41 yaş grubunda, \% 15'i 42-49 grubunda ve $\% 5$ 'i ise $50+$ yaş grubunda yeralmaktadır. Bölgede kredi kullanımı oldukça genç bir yaş grubuna ait görünmektedir. Araştırma kapsamındaki kadınlardan \% 60'ının ilk evlilik yaşlarının 13-17 yaş aralığında olduğu dikkate alınırsa aile geçimine katkı sağlamak ve gelir getirici bir faaliyete başlamanın yaşı da bir hayli düşmektedir. Eğitim durumlarına bakıldı̆̆ında; \% 23'lük kesim okur-yazar değildir, \% 10'luk kesim sadece okur-yazardır, \% 31 ilkokul, \% 25 ortaokul, \% 11 ise lise mezunudur. Genel olarak \% 33'lük kesimin formel eğitimden pay alamamış olması önemli bir oranı temsil etmektedir. Kredi kullanan kadınların doğum yerlerinin dağılımına bakıldığında; \%53'lük oran ilçede, \% 45'lik oran kent merkezinde ve \%2'lik oran ise köyde doğmuştur. Medenî durum itibariyle ele alındığında; kadınlardan \% 69'u evli, \% 24'ü bekâr, \% 6'sı dul, \% 1'i ise boşanmış durumdadır. Evlilik yaşı olarak; kadınlardan \% 59.21'i 13-17 yaş arasında, \% 36.84'ü 18-22 aralığında ve \% 3.95'i ise 23-27 yaş aralığında evlilik yapmıştır. Kadınların evlilik yaşı oldukça küçük yaşlardadır. Genç yaşlarda karşılaşılan yüksek oranın sebebi, kadınlardan resmi nikâhı olmayan \% 10'luk bir kesimi de kapsıyor olmasıdır. Çocuk sayısına bakıldığında; \% 35.53'lük kesimin 3-4, \% 30.26'lık kesimin 1-2, \% 19.74'lük kesimin 5+, \% 11.84'lük kesimin 4-5, \% 2.63'lük kesimin ise çocuğu yoktur.

Hanehalkı sayısı olarak ele alındığında \% 30’luk bir kesimin hanehalkı büyüklüğü 6 kişidir. Kadınların kocalarının aylık gelirlerine bakıldığında; \% 31.88'inin aylık geliri 500 TL., \% 
30.43'ünün asgari ücret düzeyinde, \% 24.64'ünün 1000 TL ve \% 13.04'ünün eşinin aylık geliri belirsizdir. Hane içinde karı-koca dışında çalışan bireylerin olup olmadığına yönelik soruda; \% 43'lük kesim diğer aile bireylerinin de çalıştığını, \% 56' lık kesim ise kendileri dışında çalışan olmadığını belirtmiştir. Görüşme yapılan kadınlardan hemen hemen yarısının ailesinde karıkoca dışında çocukların da çalışma yaşamına katıldığı görülmüştür. Ailede genellikle bir ya da iki çocuğun çalıştığı bildirilmiştir. Ailenin sosyal güvencelerinin olup olmadığı sorguland1ğında; \% 58'inin yeşil kartlı, \% 34'ünün SSK' 1 , \% 5'in herhangi bir sosyal güvencesinin olmadığı, \% 3'lük kesimin ise BAĞKUR'lu olduğu tespit edilmiştir. Kadınlardan \% 75'lik kesiminin yaşadığı ev kendi mülkleri, \% 25'lik kesimin ise kiralık evdir.

\section{b) Mikro Krediye Başvuru Süreci-Başvuru Kararı}

Kredi kullanan kadınlara hangi sebeplerden ötürü kredi alarak bir iş yapmaya karar verdikleri sorulduğunda tabloda gösterilen sonuçlarla karşılaşılmıştır.

Tablo 1. Kredi Kullanarak İş Yapma Sebepleri

\begin{tabular}{|l|c|}
\hline Sebep & Yüzde (\%) \\
\hline İhtiyaçların karşılanması için & $\% 61.62$ \\
\hline Parasızlık yüzünden & $\% 32.32$ \\
\hline Eşime yardımcı olmak için & $\% 6.061$ \\
\hline
\end{tabular}

Tablodan da görüldüğü gibi Diyarbakır'da örneklemimiz dâhilindeki kadınların krediye erişimleri ilk elde yeni bir girişim başlatmak ya da varolan bir işi geliştirmek hedefine hizmet etmemektedir. Acil ihtiyaçların karşılanması ve yoksulluk, nakit sıkışıklığı ya da daha net olarak parasızlık koşulları krediye yönelmede etkin olan sebeplerdir.

Krediye erişerek iş yapmak isteyen kadınların daha önceden çalışma hayatına girip girmedikleri ya da gelir getirici herhangi bir faaliyetlerinin olup olmadığı sorgulandığında kadınlardan $\% 72.73$ 'ünün herhangi bir iş deneyimi olmadığını, \% 27.27'sinin ise iş deneyimi olduğunu öğrendik. Kadınlardan önemli bir kısmının kredi kullanımı öncesine ait gelir getirici bir iş deneyimleri bulunmamaktadır.

Kredi kullanan kadınların mikro kredi programını ilk nereden ve nasıl duydukları yani ilk bilgileri nereden edindikleri yönündeki kaynaklar tabloda gösterilmiştir.

Tablo 2. Mikro Kredi ile İlgili Bilgi Kanalları

\begin{tabular}{|l|c|}
\hline Bilgi Kanalları & Yüzde (\%) \\
\hline Komşular & $\% 77.00$ \\
\hline Akrabalar & $\% 16.00$ \\
\hline Saha görevlileri & $\% 2.00$ \\
\hline Diğer & $\% 5.00$ \\
\hline
\end{tabular}

Kadınlardan \% 93'ünün mikro krediyle ilgili bilgileri komşu-akraba kaynaklarından yani resmî kanallardan değil de gayrı resmî kanallardan edinmiş olması, tanıtım hizmetlerinin yaygınlı̆̆ 1 ve yeterliliği konusunun sorgulanmasına neden olabilir. Ancak daha önemli boyut, kadınların eviçiyle, komşularla ve akrabalarla sınırlı olan sosyal dünyasında bilgi ve iletişim ağları da kisitlidir.

Mikro krediye başvuru kararının nasıl alındığı konusu tablodaki gibidir: 
Tablo 3. Krediye Başvuru Kararı

\begin{tabular}{|l|c|}
\hline Başvuru Kararı & Yüzde (\%) \\
\hline Eşle Birlikte & $\% 56.00$ \\
\hline Aile Büyükleriyle & $\% 21.00$ \\
\hline Kendim & $\% 23.00$ \\
\hline
\end{tabular}

Tablodan da görüldüğü gibi mikro krediyi alma kararında eşin büyük ölçüde belirleyiciliği söz konusudur. Kredilerin kadınların kullanımında olması öngörülürken kredi almada ve kredinin hangi alanlarda kullanılacağına karar vermede erkeklerin belirleyici olduğu durumlarla karşılaşılabilmektedir. Kadınlar krediyi kocalarının zoruyla alabilmekte veya kocalarının işleri için kullanabilmektedirler. Bu durum, kadınların evin sorumluluğunu omuzlarında taşımasından ancak kaynakların yönetiminde söz sahibi olamamasından kaynaklanmaktadır (Ergüneş, 2010, 205, 206).

Kredi almadan önce kadınların herhangi bir eleme-sınav sürecinden geçip geçmediklerine bakılırsa; kadınlardan \% 77'si sınava tâbi tutulduklarını, \% 23'ü ise sınav sürecinden geçmediklerini belirtmiştir.

c) Mikro Krediyle Yapılan İşin Niteliği, İşten Elde Edilen Gelir, Gelirin Harcama Kalemleri

Tablo 4. Mikro Kredi ile Yapılan İş

\begin{tabular}{|l|c|}
\hline Yapılan İşin Türü & Yüzde (\%) \\
\hline El İşi & $\% 78$ \\
\hline Kozmetik Ürün Satıcıllı̆ 1 & $\% 4$ \\
\hline Kuaförlük & $\% 4$ \\
\hline Nakış Atölyesi ve Terzi & $\% 7$ \\
\hline Tuhafiyecilik & $\% 1$ \\
\hline İnternet Cafe İşletmeciliği & $\% 2$ \\
\hline Market & $\% 1$ \\
\hline Sebze-Meyve Satıcılığı & $\% 1$ \\
\hline Çalışmıyorum & \\
\hline
\end{tabular}

Alınan kredilerin büyük oranda ev eksenli çalışmanın ürünleri olan el-işlerinde kullanıldığ görülmektedir. Bu sonuç, kredilerin yeni bir iş kurmak, girişimci olmak yönünde değil zaten varolan bir etkinlik alanını devam ettirmek için kullanıldığını göstermektedir. Buğra’ya göre (Buğra, 2007, 2), alınan krediler iş yapmaktan daha ziyade acil ihtiyaçların karşılanması için kullanılmaktadır. Bunun örneğine dünyada ve Türkiye'de sıklıkla rastlanmaktadır. Örneğin Adaman ve Bulut'un çalışmalarında (Adaman, \& Bulut, 2007, 75), TGMP üyelerinin \% 25'i Maya üyelerinin de \% 19 'u krediyi yeni bir işte kullandıklarını ifade ederken geri kalanlar krediyi hayatlarındaki nakit sıkışıklığını gidermek için kullandıklarını belirtmişlerdir.

Kredi iş yapmak için kullanılsa bile sonuç, yoksulların yoksullar için ürettikleri mal ve hizmet arzının artmasından başka bir şey değildir. Satın alma gücünün sınırlılığı, piyasanın daralmasına yol açmakta bu da kadınları evden dışarı çıkmaksızın geleneksel becerilerine dayalı bir üretim şekline yönlendirmektedir (Buğra, 2007, 2). Bu şekilde geleneksel yapılar korunmakta, ev ve bakım emeğinin sürekliliği garantilenmekte en önemlisi de kadının ev dışında çalışmasına karşı çıkan ataerkil düşünce yapısının yeniden üretimi sözkonusu olmaktadır. Kadının evden dışarı çıkmadan üretim yapıyor olması, kadınlarda 'çalışıyor' algısının oluşmasını da engellemekte, kadınlar yine kendilerini ‘ev hanımı’ olarak tanımlamaktadırlar. 
Mikro krediyle yapılan işten ayda ortalama ne kadar kazanç elde edildiği kadının ekonomik güçlenmesi açısından önemli bir kriter durumundadır.

Tablo 5. Yapılan İşten Elde Edilen Kazanç

\begin{tabular}{|l|c|}
\hline Elde Edilen Kazanç Miktarı & Yüzde (\%) \\
\hline $50-99$ TL. & $\% 11.00$ \\
\hline $100-199$ TL. & $\% 25.00$ \\
\hline $200-299$ TL. & $\% 28.00$ \\
\hline $300-499$ TL. & $\% 25.00$ \\
\hline $500-999$ TL. & $\% 10.00$ \\
\hline $1000-1500$ TL. & $\% 1.00$ \\
\hline
\end{tabular}

Elde edilen kazancın ağırlıklı olarak 200-300 TL arasında, eşit oranlı biçimde de 100-200 TL. ve 300-500 TL. diliminde olması, yani kadınların mevcut ekonomik faaliyetlerinden ayda maksimum 500 TL. elde ediyor olmaları ekonomik güçlenme teziyle pek uyuşmamaktadır. Ancak eşlerin gelirlerinin de en fazla asgari ücret düzeyinde olduğu, bazılarının aylık gelirinin bile belli olmadığı işsizlik ve yoksulluk koşullarında kadınların elde ettiği gelir, rutin bazı masrafların ödenmesi açısından önemli sayılmaktadır.

Elde edilen gelirin harcama modeli de kadının ekonomik güçlenmesinin önemli göstergelerinden biridir.

Tablo 6. Kazancin Harcama Modeli

\begin{tabular}{|l|c|}
\hline Harcama Modeli & Yüzde (\%) \\
\hline Kendi ihtiyaçlarımı karşıllıyorum & $\% 33.00$ \\
\hline Çocuklarımın ihtiyaçlarını karşıllyorum & $\% 31.00$ \\
\hline Evin ihtiyaçlarını karşılıyorum & $\% 20.00$ \\
\hline Mutfak masraflarını karşılıyorum & $\% 16.00$ \\
\hline
\end{tabular}

Elde edilen kazancın-gelirin- hangi kalemlere harcandığg sorulduğunda \%33'lük kesim 'kendi ihtiyaçlarımı karş1lıyorum' şeklinde cevap vermiştir. Ancak diğer dilimlere bakıldığında aslında gelirin tamamen ev içi ihtiyaçları karşılamak için kullanıldı ğı görülebilmektedir.

Kadınların elde ettiği kazancın ailenin geçimi açısından temel gelir mi yoksa ek gelir mi olduğu, kadının aile içi statüsü ve güçlenmesi bakımından önem taşımaktadır. Alanda görüşülen kadınlardan \% 87'si kendi kazancının ek gelir niteliğinde olduğunu söylerken \% 13'ü temel gelir olduğunu belirtmiştir.

Tablo 7. Aile Geçiminin Kim Tarafından Sağlandığı

\begin{tabular}{|l|c|}
\hline Aile Geçimini Kim Sağlıyor & Yüzde (\%) \\
\hline Eşim sağlıyor benim kazancım yetmiyor & $\% 53.54$ \\
\hline Babam sağlıyor & $\% 23.23$ \\
\hline Ben sağlıyorum & $\% 10.10$ \\
\hline Eşimle beraber sağlıyoruz & $\% 9.09$ \\
\hline Oğlum sağlıyor & $\% 3.03$ \\
\hline Ağabeyim sağlıyor & $\% 1.01$ \\
\hline
\end{tabular}

Aile geçiminin kim tarafından sağlandığına bakıldığında, \% 53,54'lük kesim eşinin sağladığını çünkü kendi kazancının yeterli olmadığını belirtirken, bekâr kadınları temsil eden \% 23'lük kesimde ise aile geçimi babalar tarafından sağlanmaktadır. Aile geçimi yalnızca \% 9'luk bir 
kesimde eşle beraber sağlanmaktadır. Aile geçiminin ağırlıklı olarak erkekler tarafından sağlanıyor olması, kadının kazancının yetersizliğini göstermekle birlikte krediyle yapılan işin kadını sosyo-ekonomik bakımdan güçlendireceği teziyle de uyuşmamaktadır.

Mikro krediyle yapılan işte kadınların kâra geçebilmesi ya da elde ettikleri kazançtan birikim yapabilmeleri ekonomik güçlendirmenin en önemli göstergelerinden biridir. Görüşme yapılan kadınlardan \% 74'ü herhangi bir birikim yapamadığını beyan ederken, \% 26'lık kesim yapabildiğini belirtmiştir. Neo-liberal gelişme anlayışının özü girişimcilik temasına dayanmaktadır ve bu bağlamda mikro krediler yoksul insanlardan kredilendirme yoluyla girişimci yaratarak onları yoksulluk döngüsünden kurtarmaya odaklanmıştır. Bildiğimiz üzere ekonomik bir girişimin hayatta kalması ve sürdürülebilir olması öncelikle kâr etmesine bağlıdır. Üstelik girişimleri sayesinde tasarruf yaparak kadınların bağımlılıktan kurtulacağı da mikro kredi programının varsayımları arasındadır. Alan çalışmamızdan elde ettiğimiz bulgular kadınlardan önemli bir oranının birikim elde edemediği yönündedir. Bu durum kadınların katma değeri yüksek ürünler üretmek yerine geleneksel el işlerine yönelmelerinden de kaynaklanmaktadır. Ancak bu koşullar çerçevesinde iktisadî anlamda rasyonel bir girişime ve girişimciye rastlanılamadığı açıtır.

Elde edilen gelirin geri ödemeler için yeterli olup olmadığı sorgulandığında şu sonuçla karş1laşılmıştır; kadınlardan \% 63'ü kazançlarının yeterli olduğunu belirtirken \% 37'si yeterli olmadığını beyan etmiştir. Kazanç yeterli olmadığ takdirde borç taksitlerinin nasıl ödendiğine dair sorumuza karşılık kadınlardan \% 100'ü borç alarak geri ödeme yaptıklarını beyan etmişlerdir. Örnekleme dahil olan kadınlardan geri ödemeler için kazançlarının yeterli olmadığını belirten oran azımsanmayacak düzeydedir. Bölgede kadınların dinî ve ahlâki inançları gereği ya da toplumsal anlamda aşağılanmaya maruz kalmamak için borçlarına olan sadakatleri, yeniden borçlanarak da olsa yüksek geri dönüşleri garanti etmektedir. Ancak bir borcu ödemek için yeni bir borç sarmalına girmek, zaten gelir düzeyleri oldukça düşük olan kadınlar ve ailelerini daha da yoksullaştırmak riskini içinde taşımaktadır.

Görüşülen 100 kredi kullanıcısı kadından \% 82.83'ü mikro kredi uygulaması ile ilgili herhangi bir sorun yaşamadığını bildirirken, \% 17.17'si sorun yaşadığını belirtmiştir. Yaşanan sorunlar tabloda gösterildiği gibidir.

Tablo 8. Mikro Krediyle İlgili Yaşanan Temel Sorunlar

\begin{tabular}{|l|c|}
\hline Yaşanan temel sorunlar & Yüzde (\%) \\
\hline Ödemelerin haftalık olması & $\% 62.5$ \\
\hline Haftalık ödeme yapmak için evden dışarı çıkmak & $\% 25.0$ \\
\hline Kredinin hemen çıkmaması & $\% 6.25$ \\
\hline Haftalık toplantı yapılan evden eşya kaybolması & $\% 6.25$ \\
\hline
\end{tabular}

Tablo 9. İhtiyaç Halinde Yardım Alma Kanalları

\begin{tabular}{|l|c|}
\hline Yardım Alma Kanalları & Yüzde (\%) \\
\hline Yakın komşularımdan & $\% 31.00$ \\
\hline Kendi ailemden & $\% 30.00$ \\
\hline Eşimin ailesinden & $\% 24.00$ \\
\hline Akrabalardan & $\% 8.00$ \\
\hline Banka kredisi & $\% 1.00$ \\
\hline Diğer & $\% 6.00$ \\
\hline
\end{tabular}

Bazı temel ihtiyaçlar karşılanamadığında ya da borçlar ödenemediğinde kadınların en çok kimden/kimlerden yardım aldıkları konusunda komşu ve akrabalar ön plana çıkmaktadır. Bu 
durum, kadınların ve ailelerinin yoksulluk-işsizlik koşullarındaki ayakta kalma stratejilerinde hâlâ geleneksel dayanışma ağlarının önemini ortaya koymaktadır.

\section{d) Sosyal Güçlendirme}

Araştırmamızda sosyal güçlendirmenin önemli ölçütleri olarak kadınların aile içi karar-alma mekanizmasına katılım düzeylerini ve bağımsız bir sosyo-ekonomik statü elde edip edemediklerini sorgulamaya çalıştık. Örneğin sahip olunan çocuk sayısı konusunda kadının herhangi bir tercihi ya da kararının olup olmadığı ele alındığında; kadınlardan \% 51.35'i bu konuda özgür karar veremediklerini \% 48.65'i ise aile içinde bu karara katıldıklarını belirtmiştir. Çocukların eğitimleriyle ilgili kararlarda kadınların konumu ele alındığında; kadınlardan \% 62.16'sı bu konuda eşiyle birlikte karar aldıklarını, \% 18.92'si eşinin tek başına karar aldığını, \% 18.92'lik kesim ise kendisinin bizzat karar verdiğini belirtmiştir. Kadınların çalışması ve para kazanmasına yönelik tutumlar irdelendiğinde; kadınlardan ezici çoğunluğu (\% 97.98'lik kesim) kadınların çalışması gerektiğini, \% 2.02'lik kesim ise bunu önemsemediklerini belirtmişlerdir. Kadının çalışmasını niçin önemsedikleri sorgulandığında şu sonuçlarla karşılaşılmıştır.

Tablo 10. Kadınlar Niçin Çalışmalı

\begin{tabular}{|l|c|}
\hline Kadınlar Niçin Çalışmalı & Yüzde (\%) \\
\hline Kendi ayakları üstünde durabilmek için & $\% 54.00$ \\
\hline Eşine yardım etmek için & $\% 17.00$ \\
\hline Kendi ihtiyaçlarını karşılamak için & $\% 17.00$ \\
\hline Çocuklarına bakmak için & $\% 4.00$ \\
\hline Evin geçimini sağlamak için & $\% 6.00$ \\
\hline Mecbur kaldığım için çalıştım & $\% 2.00$ \\
\hline
\end{tabular}

Kadınların çalışmasının 'kendi ayakları üstünde durabilmek' ve 'kendi ihtiyaçlarını karşılayabilmek' adına önemsenmesi kadınların bilinçlenmesinde ileri bir adımdır. Ancak bu konuda geri kalan \% 29'luk kesim, kadınların çalışmasını bağımlılıktan kurtulma, öz-güven artışı ve toplumsal bir statü elde etme bağlamında değil de, mecburiyet, evin geçimini yürütme ya da eşe yardım bağlamında önemli görmüştür.

Tablo 11. Aile İçi Şiddet Durumu

\begin{tabular}{|l|c|}
\hline Aile içi şiddet yaşandı mı? & Yüzde (\%) \\
\hline Eskiden yaşıyordum & $\% 30.00$ \\
\hline Hayır yaşamıyorum & $\% 28.00$ \\
\hline Evet yaşıyorum & $\% 20.00$ \\
\hline Bazen yaşıyorum & $\% 22.00$ \\
\hline
\end{tabular}

Toplamda \% 72'lik kesimin şiddeti deneyimlemiş olması önemli bir oranı temsil etmektedir.

Tablo 12. Kadınların Boş Zaman Faaliyetleri

\begin{tabular}{|l|c|}
\hline Boş Zaman Faaliyetleri & Yüzde (\%) \\
\hline Boş zamanım olmuyor & $\% 42.00$ \\
\hline Çocuklarıma ve eve zaman ayırıyorum & $\% 34.00$ \\
\hline Arkadaşlarımla gezmeye çıkıyorum & $\% 13.00$ \\
\hline El işi yapıyorum & $\% 11.00$ \\
\hline
\end{tabular}

Görüştüğümüz kadınlardan \% 13'lük kesim dışında kalan kesimler herhangi bir boş zaman faaliyeti belirtmek yerine boş zamanı olmadığını, ev işleri-çocuk bakımı ile ilgilendiklerini ya 
da el-işi yaptıklarını beyan etmiştir. Bu durum modern yaşamın bir getirisi olan çalışma zamanı ve boş zaman ayrımının kredi kullanarak iş yapmaya çalışan kadınlar için geçerli olmadığını göstermektedir. Kadınların çalışma dışı zamanı kendi istedikleri faaliyetlerle geçirmeleri kadınların güçlenmesinde önemli bir ölçüt sayılabilirken örneklemimize dâhil kadınlar için böyle bir göstergeden bahsedememekteyiz.

Çalışarak gelir elde ediyor olmanın kadınların hayatında neleri değiştirdiği, ele aldığımız bir başka konuydu. Bu sorumuza verilen yanıtlara göre kadınlardan \% 68'i krediyle yaptıkları işin sosyal konumlarında herhangi bir değişiklik yaratmadığı yönünde idi. Kalan \% 32'lik kesim ise çalışma ve gelir elde etmenin kendileri açısından özgürlük sağladığını beyan etmiş̧tir. Kredi alarak iş yapmaya karşı kadınların yakın çevresinin tutumlarının ne olduğu sorgulandığında, \% 80 'lik oran desteklendiğini, \% 2'lik oran desteklenmediğini, \% 17'lik oran ise tutumlarda bir değişimin olmadığını beyan etmiştir.

Tablo 13. Kadınların Hayatlarında Değiştirmek İstediği Şeyler

\begin{tabular}{|l|c|}
\hline Değiştirmek istediği şeyler & Yüzde (\%) \\
\hline Tüm hayatımı değiştirmek isterdim & $\% 34.41$ \\
\hline Evimi ve çevremi değiştirirdim & $\% 31.18$ \\
\hline Okur meslek sahibi olurdum & $\% 17.2$ \\
\hline Çocuklarıma daha iyi bir gelecek sağlamak isterdim & $\% 9.677$ \\
\hline Hasta çocuklarımı hastaneye götürürdüm & $\% 1.075$ \\
\hline Eşimi değiştirmek isterdim & $\% 6.452$ \\
\hline
\end{tabular}

\section{Sonuc}

1980'ler ve 90'larda azgelişmiş ülkelerde uygulamaya konulan yapısal uyum paketlerinin bir sonucu olarak ekonomide enformelleşme, güvencesizleşme, sendikasızlaştırma ve işgücünün artan oranda feminizasyonu, bir analiz kategorisi olarak toplumsal cinsiyetin iktisatla bütünleşmesi açısından yeni kapılar açmıştır (Beneria, 1995, 1842). Geçen yıllar içinde toplumsal cinsiyete dayalı gelişme paradigmaları yükseliş göstermiş, toplumsal cinsiyet eşitliğine dönük politikalar ve kadınların sosyo-ekonomik bakımdan güçlendirilmesi hedefi en çok vurgulanan konular olmuştur. Bu çerçevede kadınlar, mikro finans programlarının başlıca hedef grubu ve aynı zamanda 'sadık müşterileri' konumuna getirilmişlerdir. Yoksulluğun kadınsılaşması olgusuyla da paralel biçimde, toplumsal cinsiyet eşitsizlikleri ve hakim ataerkil anlayıştan kaynaklanan sebeplerle, finansal kaynaklardan dışlanan kadınların krediye erişimlerinin sağlanmasıyla, kadınların sosyo-ekonomik bakımdan güçleneceği, istihdam ve gelir firsatlarını yakalayacağı ve öz-güvenlerinin artacağı varsayılmıştır. Farklı mikro finans programlarının kadınlar açısından sonuçları da farklı olabilmektedir. Bir başlangıç sermayesine erişerek işlerini başarıyla sürdürebilen ve istihdama, düzenli gelire hatta kâra kavuşan, girişimci sıfatını edinerek toplumsal ve ekonomik statüsünü yükseltebilen kadınlar, elbette mikro finans programlarının olumlu yönünü yansitmaktadırlar.

Diyarbakır' da gerçekleştirilen alan araştırmasının bulguları çerçevesinde, görüşülen kadınlar arasında 'ekonomik güçlendirme' yönündeki sonuçlara bakıldığında, en başta mikro krediye başvuru kararının alınmasında erkeğin belirleyici konumda olması, herhangi bir ekonomik girişimi başlatma ve bir başlangıç sermayesine erişim konusunda kadınların bağımsız karar veremediklerinin bir göstergesi sayılmalıdır. Kadınların kredi ile bir iş yapma gerekçelerinde 'ihtiyaçların karşılanması' hususunun vurgulanmış olması, kredilerin genellikle hanedeki borçların ödenmesi ya da acil ihtiyaçların karşılanması için kullanıldığı yönündeki araştırma sonuçlarıyla bağdaşmaktadır. Kredi kullanarak yapılan işler, geleneksel ev-içi üretim özelliği gösteren işler olup, ev dışında güvenceli, düzenli gelir getiren ve kadınları kamusal hayata 
sokan işler değildir. Mikro kredi ile yapılan işten elde edilen kazancın düşüklügü, kadının ekonomik bakımdan güçlenmesi teziyle uyuşmamaktadır. Ailenin geçiminde erkeğin belirleyici olması ve kadının kazancının erkekle eş düzeyde olmayıp ek gelir statüsünden bir türlü kurtulamayışı, sosyo-ekonomik bakımdan kadının statüsünde de bir değişim yaratmamaktadır. Kadının elde ettiği kazancın daima aile içi ihtiyaçların karşılanmasında kullanılışı, kazançtan birikim yapma olanağının bulunmayışı, kazancın düşüklüğünü göstermektedir. Kadının bağımsız harcama yapamayışı ve ekonomik kaynaklar üzerinde kontrol sahibi olamayışı, ataerkil değerlerin baskınlığıyla açıklanabilir. Kadınların yaptıkları işlerden elde ettikleri gelirin yüksek olmamasına rağmen, geri ödemelerin düzenli yapıllyor olması önemli bir buldugur. Ancak geri ödemedeki sorumluluk ve yaşanılan sıkıntılar doğrudan kadınları etkilemektedir ve nitekim kadınlar ödemelerin haftalık olmasından yakınmaktadırlar. Geri ödemelerde sosyal teminat olarak işlev gören dayanışma grupları, kadınlar açısından bir 'bilgi' ve gerektiğinde 'borç alma' kanalı olmakta, kadınlar el emeği ürünlerini bu yolla pazarlama firsatı elde etmektedirler. Ancak dayanışma gruplarıyla sınırlı bir sosyal dünya içinde kalan kadınların sosyal ilişki ağlarının ve hareketliliklerinin varsayıldığı gibi güçlenemeyeceği düşünülebilir.

Sosyal güçlendirme konusunda, kadının para kazanıyor olmasının sosyal açıdan onu özgür kılmaması, aile içi karar alma mekanizmasına kadının sınırlı katılımı (örneğin çocuk sayısına karar vermede kadının etkin olmayışı) güçlendirme mantığına uygun düşmemektedir. Kadının sosyal hayat açısından yeterli zamanının olmaması, zaman baskısına ve iş yoğunlaşmasına maruz kalması, serbest zamanın değerlendirilmesinde de eşten izin alınarak hareket edilmesi, özgürleşimin önündeki engellerdir. Görüşülen kadınların önemli oranının aile içi şiddet yaşamış/yaşıyor oluşu da güçlenen kadın imajıyla uyuşmamaktadır. Son noktada kadınların ellerinde imkân olsa tüm hayatlarını değiştirmek istediklerini beyan etmeleri de oldukça anlamlıdır.

Araştırmanın Diyarbakır gibi yoğun göç alan, iş imkânlarının hem erkekler hem de kadınlar için hayli kısıtlı olduğu ve yoksulluğun derinleşmiş olduğu bir kentte yapılmış olması, mikro kredi uygulamasının bu bölgedeki sonuçlarının genelgeçer sayılmasını zorlaştırmaktadır. Görüşülen kadınların çoğu geleneksel-ataerkil kültürde yetişmiş, şiddet görmüş ve eğitim düzeyleri düşük kadınlardır. Başka bölgelerde mikro kredi uygulaması başka koşullarda işleyebilir ve farklı sonuçlar doğurabilir. Bu bakımdan araştırmayı yoksulluğun yoğun biçimde yaşandığı ve ataerkil aile ve toplum yapısının hakim olduğu bir bölgede yapmış olmak, çalışma açısından bir kısıtlılık sayılabilir. Bu konudaki alan araştırmalarının çeşitlendirilmesi, konuyla ilgili farklı bulgulara erişilmesini sağlayacak ve literatürün zenginleşmesine büyük ölçüde katkı sunacaktır.

Toplumda kadınları güçsüzleştiren en önemli etmenler yoksulluk ve parasızlık olduğu kadar hâkim ataerkil ideolojiye dayalı toplumsal cinsiyet eşitsizlikleridir. Bu eşitsizlikler toplumda ve aile içinde kadınların konumunu ikincilleştirmekte ve kadınların eğitime, istihdama, gelire, finansal kaynaklara ve sosyal statüye erişimlerini engellemekte ya da kısıtlamaktadır. Bu bakımdan kadınların güçlendirilmesi yalnızca finansal kaynaklara erişimlerini sağlamakla değil, onları eşitsizlikçi ilişkiler ağından kurtarıp ikincil konumlarından uzaklaştırmayla mümkün olabilir. Güçlendirmeyi amaç edinen mikro kredi programlarının toplumsal cinsiyet perspektifini geliştirip kadınları kamusal hayata entegre edecek mekanizmalar yaratması gerekmektedir. 


\section{KAYNAKÇA}

Adaman, F., \& Bulut, T. (2007). Diyarbakır'dan İstanbul'a 500 Milyonluk Umut Hikâyeleri: Mikro kredi Maceraları. İstanbul: İletişim Yayınları.

Baltacı, N. Ö. (2011). "Kadınları Güçlendirme Mekanizması Olarak Mikro Kredi”. Uzmanlık Tezi. Başbakanlık Kadının Statüsü Genel Müdürlüğü, Ankara.

Beneria, L. (1995). "Toward a Greater Integration of Gender in Economics". World Development, 23/11, 1839-1850.

Buğra, A. (2007). "Yoksullukla Mücadele Yöntemi Olarak Mikrokredi: Acıklı Bir Hikâye". B.Ü Sosyal Politika Forumu Bülteni, 2, 1-4.

Cheston, S., \& Kuhn, L. (2002). "Empowering Women through Micro finance' Opportunity International". http://www.microcreditsummit.org/papers/empowerment.pdf.

Ergüneş, N. (2010) "Kadınlara Yönelik Kredi Biçimleri ve Kadın Emeğinin Enformelleşmesi”. Der. Saniye Dedeoğlu, \& Melda Yaman Öztürk. Kapitalizm, Ataerkillik ve Kadın Emeği, 183-215, İstanbul: SAV Yayınları.

Goetz, A. M., \& Sen, Gupta, R. (1996). "Who Takes the Credit? Gender, Power and Control Over Loan Use in Rural Credit Programs in Bangladesh". World Development, 24/1, 45-63.

Hashemi, M. S., Schuler, S. R., \& Riley, A. P. (1996). 'Rural Credit Programs and Women's Empowerment in Bangladesh'. World Development, 24/4, 635-653.

Isserles, R. G. (2003). "Micro Credit: The Rhetoric of Empowerment, the Reality of Development as Usual". Women's Studies Quarterly, 31 (3/4), 38-57.

Kabeer, N. (2005). "Gender Equality and Women's Empowerment: A Critical Analysis of the Third Millennium Development Goal (MDG) ". Gender and Development, 13/1, 13-24.

Mayoux, L. (1995). "From Vicious to Virtuous Circles?: Gender and Micro-Enterprise Development". Occasional Paper, UN Research Institute for Social Development, UN Development Programme.

Mayoux, L. (2006). "Women's Empowerment through Sustainable Micro-finans: Rethinking Best Practise". Discussion Draft. http://www.genfinance.net.

Rahman, A. (1999). "Micro-credit Initiatives for Equitable and Sustainable Development: Who Pays?". World Development, 27/1, 67-82.

Rankin, N. Katharine (2001). "Governing Development: Neoliberalism, Microcredit and Rational Economic Woman". Economy and Society, 30/1, 18-37.

Sanyal, P. (2009). "From Credit to Collective Action: The Role of Microfinance in Promoting Women's Social Capital and Normative Influence". American Sociological Review, Vol. 74 August, 529-550.

Simojoki, H. K. (2003). "Empowering Credit More than Just Money: The Socio Economic Impact of Micro Finance on Women in Nairobi”. Kenya. https://jyx.jyu.fi/dspace/bitstream/handle/123456789/ G0000086.pdf?sequence=1

Toksöz, G. (2012). Kalkınmada Kadın Emeği. İstanbul: Varlık Yayınları.

"The Republic of Turkey Prime Ministry General Directorate on the Status of Women" (2008). National Action Plan Gender Equality. 2008-2013, Ankara.

http://www.undp.org.tr/Gozlem3.aspx?WebSayfaNo=618 Erişim: 04.10.2013

www.eski.bianet.org Erişim: 04.10.2013

www.tgmp.net Erişim: 04.10.2013 